\title{
Improvement of Supply Chain Risk Management Algorithm using Modern Technologies
}

\author{
Sushkova Olena, Tumanova Elena, Bekirova Sevil, Bondar Aleksandr, Voroshilo Viktoria
}

\begin{abstract}
Essence of the risk management model in supply chains of enterprises is investigated in the article. Classification of type risks faced by enterprises in construction of their own supply chains is considered. The SCRM model is analyzed as a supply chain management tool. Necessity to introduce a risk management algorithm at enterprise using modern technologies is substantiated. Structural elements and relationships of the supply chain risk management algorithm are identified. It is justified that one of the most effective tools for identifying and analyzing risks in supply chain is big data, which should include information about the participants (elements) of the supply chain; resources used by supply chain members and / or moving between its elements; logistics processes that occur at each stage of the supply chain. It is also established that the use of block chain technology will ensure the integrity, reliability and security of information, which will form the basis of big data risk management in the supply chain, and the effective functioning of the entire supply chain risk management system.
\end{abstract}

Keywords : factors of risk in supply chain, risk types, supply chain risk management, big data, decision analysis.

\section{INTRODUCTION}

Development of integration processes in economy and their departure from main economic links along lines of interaction with business partners in sphere of supply and marketing of finished products led to emergence of concept of "integrated logistics" in the early 1980s, or " supply chain logistics. Accordingly, concept of supply chain management (SCM) has been developed in integrated logistics management [1]. According to the definition of European Logistics Association, SCM is an integrated approach to business that reveals fundamental principles of management in logistics chain, such as formation of functional strategies, organizational structure, decision-making methods, resource management, implementation of support functions, systems and procedures.

In process of evolution, conceptual apparatus of concept SCM has changed significantly. For example, SCOR-model (supply-chain operations reference-model), recommended by international organization - The Supply-Chain Council (SCC). SCOR model provides its own language to describe

Revised Version Manuscript Received on October 15, 2019.

Sushkova Olena, Department of Customs, University of the State Fiscal Service of Ukraine, Irpin, Ukraine. Email: elenasushkova@ukr.net

Tumanova Elena, FSAEI HE «V.I. Vernadsky Crimean Federal University, Simferopol. Ukraine Email: elantu@ rambler.ru.

Bekirova Sevil, Department of agribusiness economics, Institute of Economics and Management (structural subdivision), FSAEI HE «V.I Vernadsky Crimean Federal University», Simferopol. Ukraine Email: bekes@inbox.ru

Bondar Aleksandr, FSAEI HE «V.I. Vernadsky Crimean Federal University», Simferopol. Ukraine Email: bondar-ap2014@yandex.ru

Voroshilo Viktoria, FSAEI HE «V.I. Vernadsky Crimean Federal University», Simferopol, Ukraine Email: mivik06@mail.ru supply chain participants. This model uses a system for evaluating effectiveness of chain and business processes. Model provides a graphical representation of supply chain and network structure of an integrated business in terms of material flow in production cycle of product. In addition, SCOR-model is an effective tool for supply chain diagnostics, identifies bottlenecks and presents possible alternatives to building a company logistics system. [2]

In order to develop and improve SCOR-model, Supply Chain Council has developed DCOR-model (design chain operations reference model), a recommended design chain operations model that covers product creation processes. DCOR-model is based on a description of basic business processes: research, design, integrate, amend, combined by plan scheduling function. . It should be noted that process categories of DCOR-model focus on three areas of innovation: product refresh, new product, new technology. DCOR-model can be used both individually and in conjunction with SCOR-model.

Supply Chain Council also envisages development of a third model - CCOR-model (customer chain operations reference model) - a recommended model for consumer chains, which together with two existing IBRF-model (integrated business reference framework model) is recommended integrated business structure. IBRF-model is a business planning tool that can integrate value chain management across the product life cycle. With introduction of this structure, it will be the first time that product chain, supply chain and consumer chain can be integrated into full value chain of product.

In context that one of the stages of management is risk management, concept of SC risk management (SCRM) has been developed as a means of mitigating their risks) [3]. However, dynamics of economic environment, market volatility, financial and information secrecy from counterparties, information integration problems, etc. necessitate improvement of SCRM model in light of current market requirements and new information technologies, to develop and justify algorithm of application of this model in management process.

\section{LITERATURE REVIEW}

Work of Ukrainian and foreign scientists is devoted to study problems of supply chain management, in particular the analysis of risks in supply chains. 
Chandak, A. Gangele in article «Influence of Supply Chain Management Strategy on Supply Chain Management Performance a Statistical Model Analysis in Context of Indian Automobile Industry» have characterized features of supply chain management (SCM), as they become the focus of much attention in many organizations. Scholars have also explored SCM strategies and their impact on SCM performance in industrial car manufacturing in India. The current expertise in SCM is highlighted. In addition, article examines SCMS and SCMP associations and relationships [4].

Purposes of this study «The Educational Logistic Potential and Supply Chain Link to Agro-Tourism Through Learning the Lifestyle Amphoe Lansaka, Nakorn Sri Thammarat» were to examine readiness and accordance of potential, demand of logistics potential and agro-tourism supply chain in Lan Saka district, Nakhon Si Thammarat province. [5]

In the work «Problems in a achieving consensus in sustainable supply chain formatin» by Mikita Lushcheuski the main objective is to find actions or technologies which might facilitate interaction among different supply chain members or help to achieve consensus in the sustainable supply chain formation [6]. M. Lushcheuski argue that one of management process and achieving consensus in sustainable supply chain formation is the implementation of blockchain-based technologies and smart contracts. On one hand blockchain technologies can increase the speed of material, good, service, cash, and information flows, the possibilities of frauds.

On the other hand, the authors of the study "Highlighting the importance of considering impacts of both external and internal risk factors on operational parameters to improve Supply Chain Risk Management" argue that operational risk management in supply chain activities is important for the successful achievement of the desired outcomes [7]. The authors proposed an approach that allows to analyze the supply chain both from the perspective of events local to the supply chain and from the perspective of external events as they will directly influence the internal ones. Then the authors consider supply chain risk management not only as an operational research process, as do all the relevant survey papers, but a data science problem to gain deeper real-time insights for information risk management.

Considering the considerable contribution of foreign and domestic scientists, it should be noted that in the current conditions of dynamic development of economy and information technologies, the issue of improving supply chain risk management algorithm with use of modern technologies becomes relevant.

\section{METHODOLOGY AND RESERCH DESICN}

In order to develop a risk management algorithm in supply chain using modern technologies, in this article methods of systematization and interpretation (to systematize the types of risks in the supply chain), methods of abstraction and concretization, logical analysis (in determining the components of the risk management algorithm in supply chain) ), a method of system-structural analysis (to build an algorithm and an improved structure of supply chain, taking into account developed risk management algorithm), a the best solutions for improving the supply chain

graphical method and a simulation method (in the process of interpreting results of developing a supply chain risk management algorithm).

\section{RESULT AND DISCUSSION}

Logistics chain can be defined as channel through which products are transferred from supplier to the end consumer. It is influenced by virtually all functions performed by its members. An insecure supply chain may pose a risk that company will not be able to identify in advance. In addition, protection against theft of material and intellectual assets of company requires a comprehensive system of risk management in enterprise. Managing organizational change in supply chains can be managed based on five key principles: FAST; bench marking processes; process engineering; process re engineering; supply chain optimization.

European companies and companies practice their logistics activities using the following seven rules (7R righting) or as they are called seven "needs": 1) Product right product; 2) Quantity - in required amount; 3) Quality required quality; 4) Time - must be delivered at right time; 5) Place - in right place; 6) Costs - with minimal costs; 7) Client - right client. On the one hand, for each supply chain, these 7 principles are a set of established and prescribed rules, deviations from which are undesirable and in some cases not even acceptable. Only if all seven rules are fulfilled, logistics system will achieve efficiency, effectiveness and rationality in its activity [8]. Therefore, on the other hand, these 7 principles are sources (factors) of risk that determine its occurrence (Fig. 1). But in addition to these "classic" logistics components, in our opinion, formation of supply chain must take into account security components and risk management.

Systematization of factors risks allows working out the effective system of their exposure and prognostication. In turn the detailed description (classification) risks performs the certain duty of algorithm on the basis that control system by risks is developed and created, instruments and measures will be determined in relation to minimization of negative influence on the object management in conditions of vagueness and multi-variant approach development. Defense of chain supplies means development and application of measures providing process and minimization risks in area of all chain. To that end a large value is acquired by classification of risks on a sphere (in relation to a chain) and implementation of chain supplies (phases table 1).

Above classification shows that process of planning and risk minimization applies to both internal and external environment of enterprise and begins with production of goods and ends with their delivery. In addition, it can be noted that there are different forms of risks for supply chains. For example, the problem of industrial espionage is the most pressing in Germany, China, Russia and Iran (according to the data presented in the TAPA - Transported Asset Protection Association) [9; 10]. According to preliminary estimates of security experts, annual losses for Germany amount to tens of billions euros. Chinese spies are 
intentionally looking for innovative products to expand their own technical and economic know-how. Another example of illegal logistical activity is theft of goods and such incidents have been quite common in Europe in recent years. Figures presented by TAPA (Transported Asset Protection Association) indicate a sharp and alarming increase in number of stolen vehicles and goods, goods stolen from trailers or warehouses. Based on TARA data, Germany counted 192 cargo and warehouse thefts during the first three quarters of 2018. Based on TARA data, in the first quarter of 2019 alone, 697 cargo and warehouse thefts occurred in 65 countries. The following countries suffered the greatest
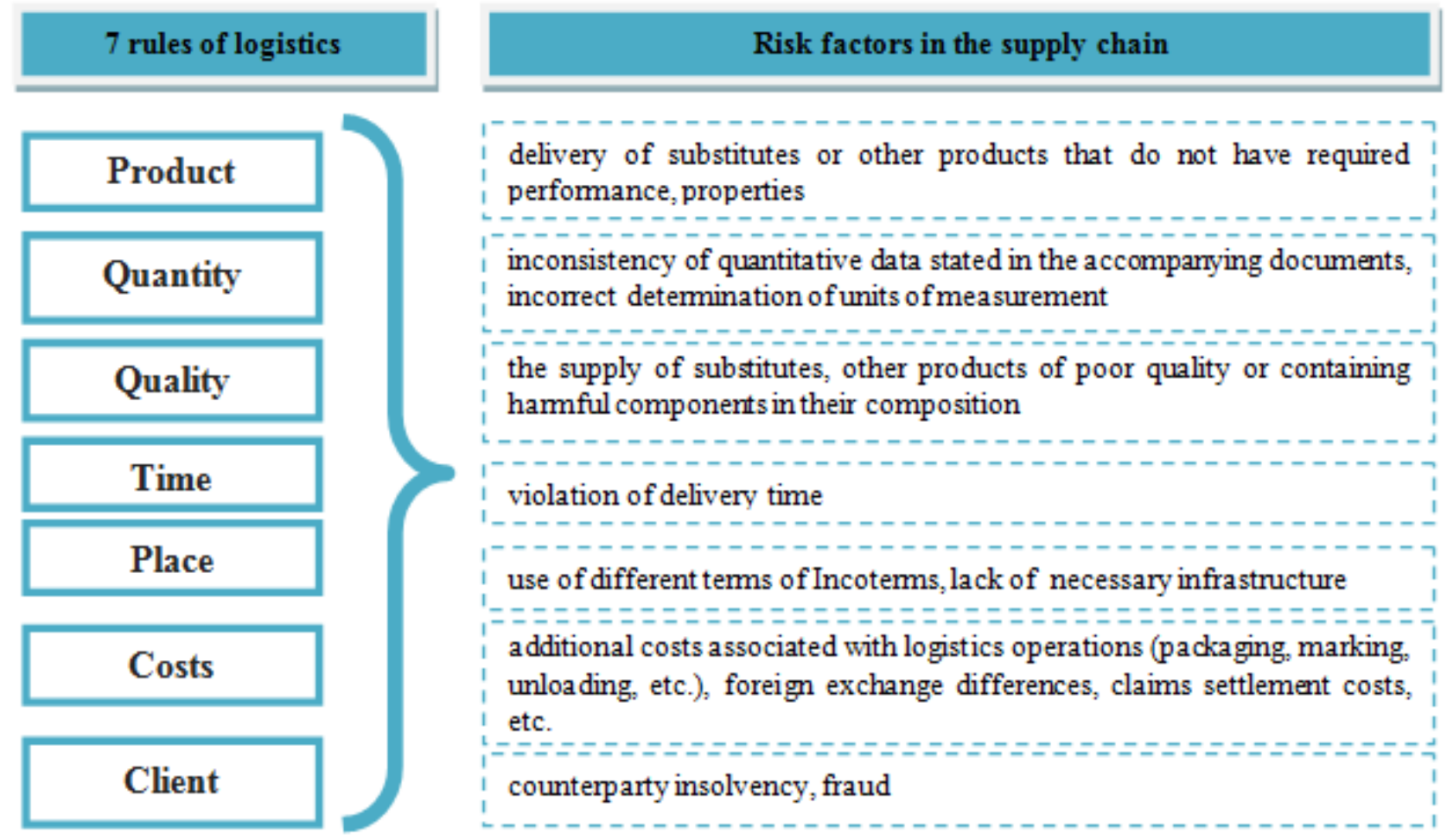

It should be noted that the main condition for the effective operation of the above figure 2 algorithm is a large array of information that must meet the requirements of reliability,

Table 1: Classification of Risk Types in SC [12, p. 5]

\begin{tabular}{|c|c|c|c|}
\hline \multicolumn{2}{|c|}{ Internal risk types } & \multicolumn{2}{|c|}{ External risk types } \\
\hline Type & Description & Type & Description \\
\hline $\begin{array}{l}\text { Plan } \\
\text { risks }\end{array}$ & $\begin{array}{l}\text { occur in input information regarding } \\
\text { demand and supply, capacity and } \\
\text { resources }\end{array}$ & \multirow[t]{2}{*}{$\begin{array}{l}\text { Environmental } \\
\text { risks }\end{array}$} & \multirow{2}{*}{$\begin{array}{l}\text { emanate from outside SC, are often related to } \\
\text { social, economic, governmental and climatic } \\
\text { factors and lead to additional supply and demand } \\
\text { risks }\end{array}$} \\
\hline $\begin{array}{l}\text { Source } \\
\text { risks }\end{array}$ & $\begin{array}{l}\text { occur while collecting information and } \\
\text { materials in the planning process of SCM }\end{array}$ & & \\
\hline $\begin{array}{l}\text { Make } \\
\text { risks }\end{array}$ & $\begin{array}{l}\text { occur while obtaining resources } \\
\text { transformed into products and/or services }\end{array}$ & \multirow[t]{2}{*}{ Business risks } & \multirow{2}{*}{$\begin{array}{l}\text { occur as a result of external factors that impact } \\
\text { on management stability, suppliers' finances, } \\
\text { and/or supplier firms' sales and purchases }\end{array}$} \\
\hline $\begin{array}{l}\text { Delivery } \\
\text { risks }\end{array}$ & $\begin{array}{l}\text { occur while requesting and transporting } \\
\text { order/product }\end{array}$ & & \\
\hline $\begin{array}{l}\text { Return } \\
\text { risks }\end{array}$ & $\begin{array}{l}\text { occur when receiving material flows, } \\
\text { services and/or products }\end{array}$ & $\begin{array}{l}\text { Physical plant } \\
\text { risks }\end{array}$ & $\begin{array}{l}\text { occur due to events impacting on condition of } \\
\text { supplier's physical facility and regulatory } \\
\text { compliance }\end{array}$ \\
\hline
\end{tabular}

relevance, measurability. Figure 1. Factors of risk in supply

financial and commodity losses: Great Britain (95 thefts), Netherlands (90), Germany (55), Spain (45) and Italy (42), the same period last year [11, p. 12].

Therefore, in order to prevent or minimize supply risks, we propose to perform a risk analysis using the algorithm shown the supply chain (quantity, quality, place, time, etc.) on the basis of establishing a system of appropriate indicators and on the basis of this information to determine effective methods of counteracting risks.

chain 


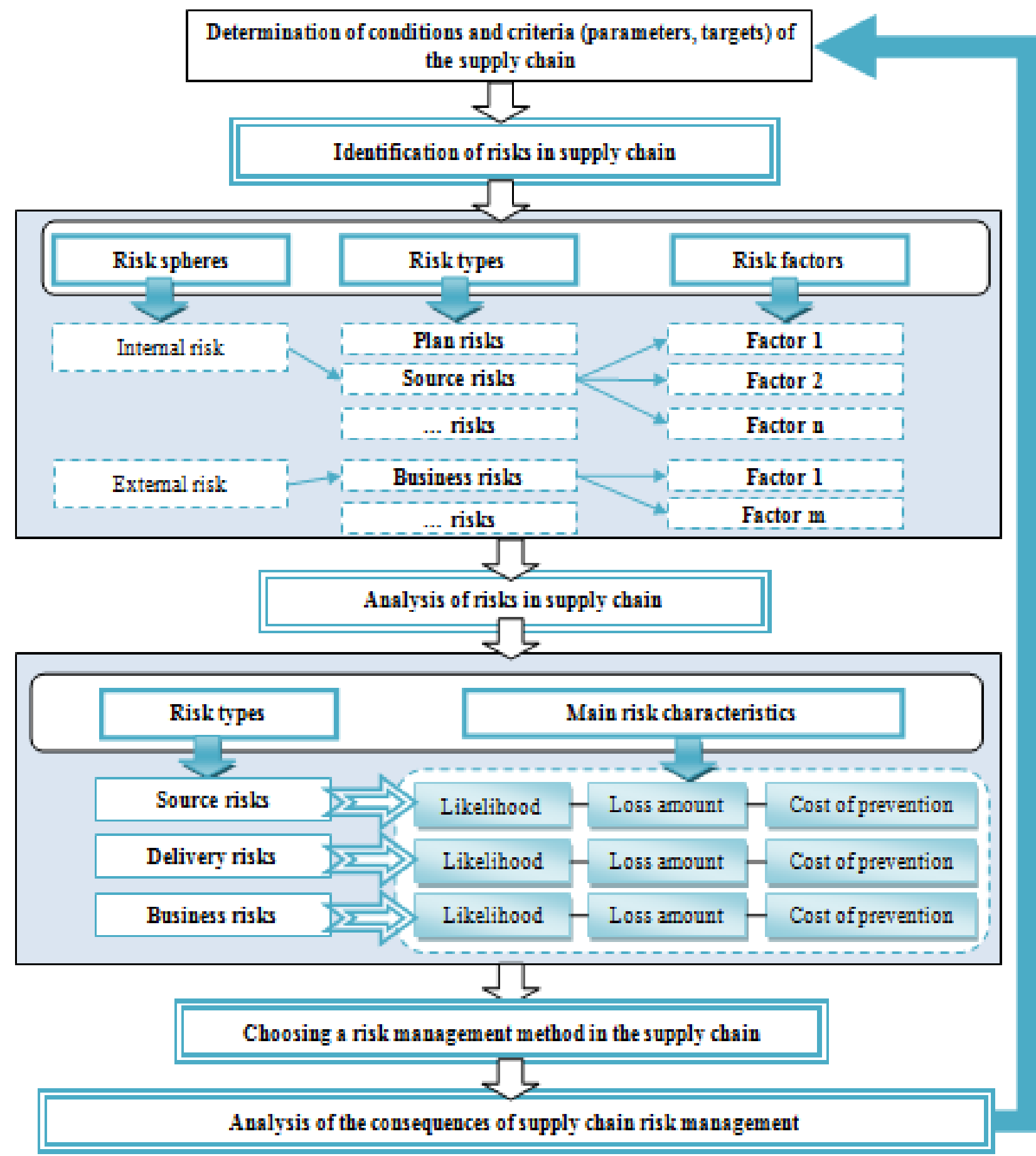

Figure 2. Algorithm of supply chain risk management

Besides one term of origin risk there is null information about a situation (event, future), and that is why one of the most effective instruments of management risks (identify and analysis) in the chain of deliveries, to our opinion, is big data. If to take the classic model of conception SCM for basis, then big data with the aim of management risks (rice. 3) must include next information:

1) in relation to the participants (elements) of chain deliveries;

2) in relation to resources that is used by the participants of chain deliveries and/or move between his elements;

3 ) in relation to logistic processes that take place on every stage of chain deliveries.

Thus, all this information must be complemented by indexes (by indicators) after that it is possible risks in the chain deliveries to identify, to estimate (qualitatively or in number) and classify after a level.

In order to accumulate, exchange, transmit, preserve the integrity of information and evaluate risk based on each stage of supply chain, blockchain technology, which is an ever-increasing sequence of information blocks (each subsequent block contains information about the previous block), may be promising, which:

- stored simultaneously by all network users;

- constantly updated and refer to old blocks;

- are shared between participants through peer-to-peer networks

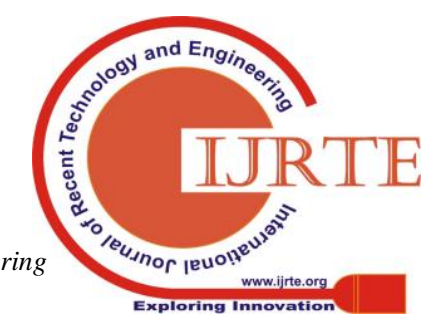




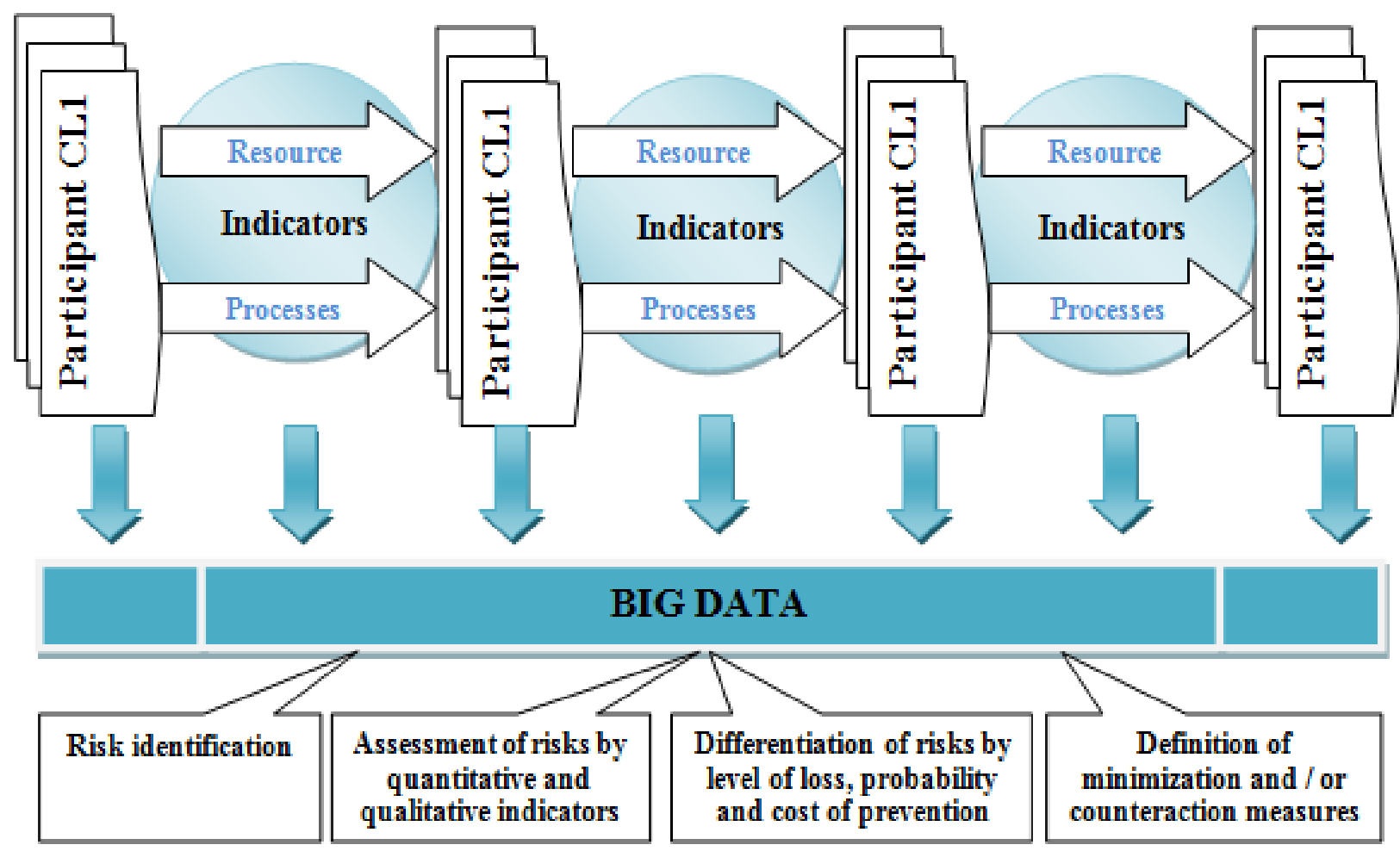

Figure 3. Improved supply chain structure, taking into account the developed risk management algorithm

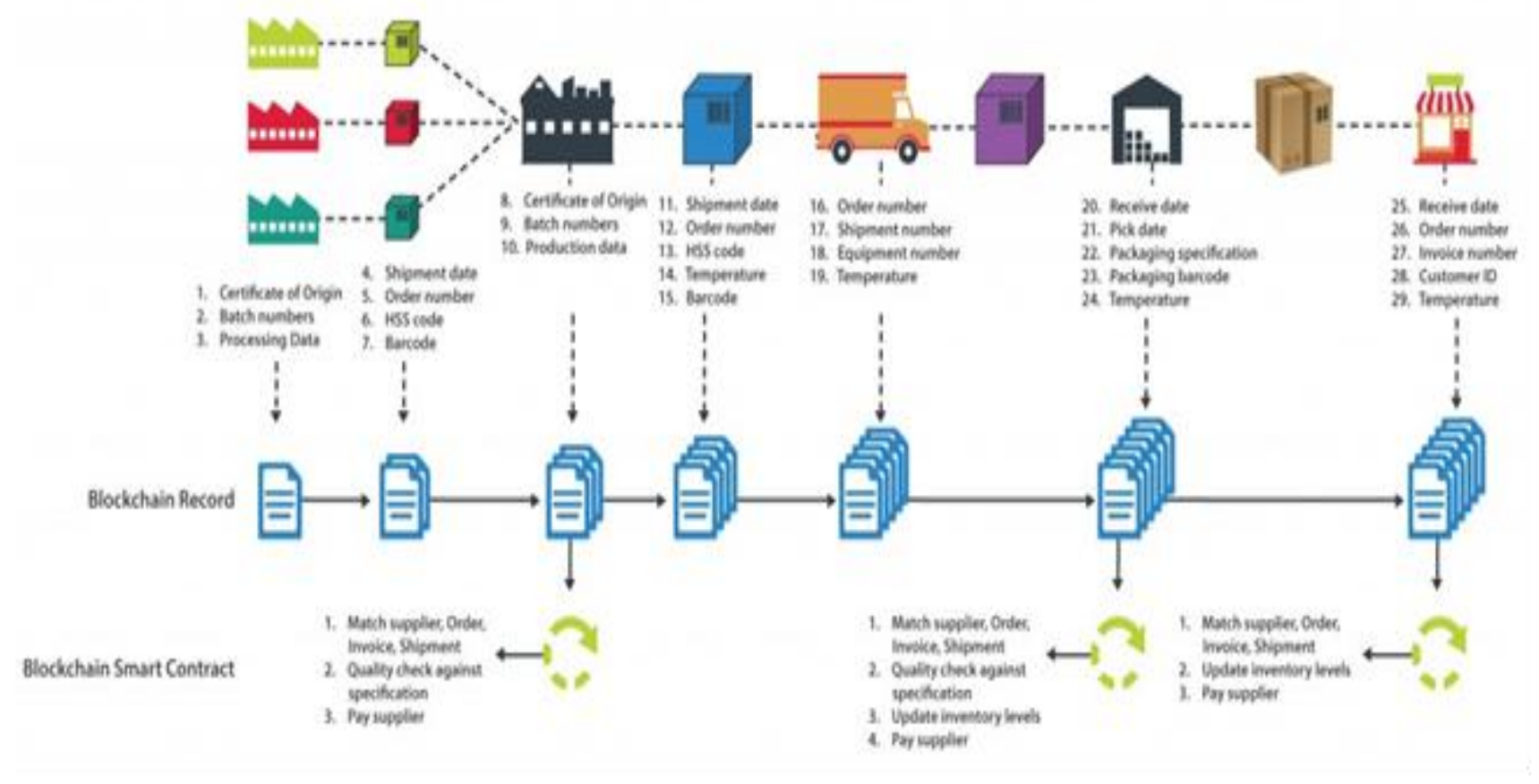

Figure 4. Basic blockchain diagram in supply chain logistics [13]

A timestamp (hash) is added to each block, which is most easily imagined as a unique fingerprint. These blocks are strictly in a certain order in chains. If you try to delete or add a block, system immediately turns to tens of thousands other versions of this book and detects a mismatch in the block structure due to a hash sum mismatch. To protect against changes in timestamps and hash sums, block chain uses several methods of protection: Proof of Work (PoW, proof of work) and Proof of Stake (PoS, proof of ownership) [14]. Thus, use of block chain technology will ensure the integrity, authenticity and security of information, which will form the basis of big data risk management in the supply chain. And this will ensure the efficient operation of the entire system

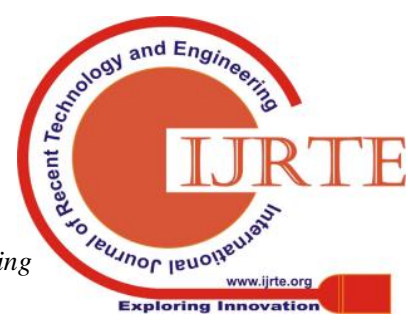




\section{CONCLUSION}

Level of development SCM both today and in the future will be a major factor in competition between enterprises, economic regions and countries. In doing so, reliable security in the supply chain will be a key element in gaining competitive advantage. Another competitive advantage, in our opinion, could be to build simultaneously efficient, flexible and responsible supply chains that meet the current requirements of digitization.

Thus, use of modern technologies in supply chain risk management will help optimize information flow, reduce costs and prevent risks and fraud in the field of foreign economic activity. Block chain technology will allow supply chain logistics to be transparent, understandable and predictable, providing big data risk management systems with comprehensive, reliable and secure information.

Further research should be directed to the development of an analytical component of big data risk management system in the supply chain of goods.

\section{ACKNOWLEDGMENT}

Work was carried out within research work on the subject "Development of customs policy of Ukraine in context of realization economic function of the state" (state registration number №0118U003628) 2017-2021 years.

\section{REFERENCES}

1. Mentzer J., DeWitt W., Keebler J., Min S., Nix N., Smith C., Zacharia Z. 2001. Defining supply chain management. Journal of Business Logistics. Vol. 22, No. 2. p. 1-25. https://doi.org/10.1002/j.2158-1592.2001.tb00001.x

2. Harrison T.P., Lee H.L., Neale J. J. Principles for the strategic design of supply chains // The Practice of Supply Chain Management. New York : Springer, 2005. Pp. 3-12. [Online]. Available: https://link.springer.com/chapter/10.1007/0-387-27275-5 _1. Accessed on: Nov. 12, 2019.

3. Abdullah Salamai, Omar K Hussain, Morteza Saberi, Elizabeth Chang, Farookh Khadeer Hussain. (2019). "Highlighting the importance of considering the impacts of both external and internal risk factors on operational parameters to improve Supply Chain Risk Management". DOI 10.1109/ACCESS.2019.2902191, IEEE Access.

4. A. Chandak, A. Gangele «Influence of Supply Chain Management Strategy on Supply Chain Management Performance a Statistical Model Analysis in Context of Indian Automobile Industry» International Journal of Recent Technology and Engineering (IJRTE), Vol.8, Issue-2S2, 2019. [Online]. Available: https://www.ijrte.org/wp-content/uploads/papers/v8i1/A3 384058119.pdf

5. W. Tiranan., J. Krittika, K. Nuchakorn «The Educational Logistic Potential and Supply Chain Link to Agro-Tourism Through Learning the Lifestyle Amphoe Lansaka, Nakorn Sri Thammarat» International Journal of Recent Technology and Engineering (IJRTE), Vol.8, Issue-2S2, 2019 DOI: 10.35940/ijrte.B1020.0782S219. [Online]. Available: https://www.ijrte.org/wp-content/uploads/papers/v8i2S2/ B10200782S219.pdf Accessed on: Nov. 12, 2019.

6. Mikita Lushcheuski. "Problems in achieving consensus in sustainable supply chain formation" : bachelor's thesis Degree programme in business logistics. South-Eastern Finland University of Applied Science, April 2019, 45 p. [Online].

Available:
https://www.theseus.fi/bitstream/handle/10024/166548/L ushcheuski_Mikita.pdf?sequence $=2$ \&isAllowed $=y$ Accessed on: Nov. 12, 2019.

7. Abdullah Salamai, Omar K Hussain, Morteza Saberi, Elizabeth Chang, Farookh Khadeer Hussain. (2019). "Highlighting the importance of considering the impacts of both external and internal risk factors on operational parameters to improve Supply Chain Risk Management". DOI 10.1109/ACCESS.2019.2902191, IEEE Access.

8. Logistyka: teoriia, sytuatsii, praktychni zavdannia / Chastyna. Logistyka yak instrument rynkovoi ekonomiky: Navch. posibnyk / Za zag. red. O.M. Sumtsia / O.M. Sumets', O.B. Bilotserkovs'kyi, I.P. Golofayeva. Kharkiv: Mis'kdruk, 2010. - 212 p. (In Ukrainian)

9. Christopher M. 1998. Logistics and Supply Chain Management: Strategies for Reducing Costs and Improve Services. London: Financial Times/Pitman. [Online]. Available: https://doi.org/10.1080/13675569908901575 Accessed on: Nov. 12, 2019.

10. Community of Logistics and Supply Chain Management: [Online]. Available: www.logistician.ru. Accessed on: Nov. 12, 2019.

11. Vigilant: the monthly cargo crime update for TAPA's global family / newsletter [Online]. Available: https://tapa.memberclicks.net/assets/VIGILANT-NEWS LETTER/TAPA\%20Vigilant\%20e-Magazine\%20Octobe r\%202019.pdf

12. Abdullah Salamai, Omar K Hussain, Morteza Saberi, Elizabeth Chang, Farookh Khadeer Hussain. (2019) "Highlighting the importance of considering the impacts of both external and internal risk factors on operational parameters to improve Supply Chain Risk Management". DOI 10.1109/ACCESS.2019.2902191, IEEE Access.

13. "Blockchain as the future technology will be used in logistics" Logistic company «ABL», official site. [Online]. Available:

http://www.ablcompany.ru/news/blokcheyn-kak-tehnolo giya-budushchego-budet-ispolzovana-v-logistike Accessed on: Nov. 12, 2019.

14. "Blockchain as the future technology will be used in logistics" Logistic company «ABL», official site. [Online] Available:

http://www.ablcompany.ru/news/blokcheyn-kak-tehnolo giya-budushchego-budet-ispolzovana-v-logistike Accessed on: Nov. 12, 2019.

\section{AUTHORS PROFILE}

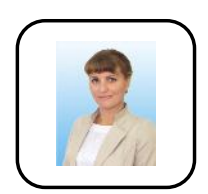

Sushkova Olena, $\mathrm{PhD}$, Associate Professor, University of the State Fiscal Service of Ukraine, Irpin, Ukraine

Dissertation research «Providing the tax regulation of the regional economic development» (2012)

Leader of three research topics on tax risk management and identifying effective tools to prevent tax law violations. Author of 115 publications, including 28 articles; co-author of three monographs (one of which is a foreign monograph), 4 textbooks.

Research interests: risk management, tax risk, customs risk, supply chain management.

ORCID iD 0000-0002-8748-7864

Google Scholar ID:

https://scholar.google.com/citations?user=EpgAAB0AAAAJ\&hl=ru 
Bondar Aleksandr, $\mathrm{PhD}$, Associate Professor,

V. I. Vernadsky Crimean Federal University, Simferopol

The theme of the protected dissertation in 2002 "Lending to consumers for consumer needs". He is the author of 140 publications, of which 10 are collective monographs, 2 articles in Scopus scientific-metric database, 25 articles in professional editions of Ukraine, 160 articles and abstracts in collections of scientific-practical conferences, co-author of 4 textbooks.

Research interests: banking, banking management, financial management, risk management, consumer credit

Scopus Author ID: $\mathbf{5 7 1 9 3 8 5 7 5 0 5}$

ORCID iD 0000-0002-2530-6095

Google Scholar iD:

https://scholar.google.com/citations?hl=ru\&view_op=list_works\&gmla =AJsN-F4OeiyOZUiSf4MTcts3ckuYr-95mETxe9EBj0dicdl-103WHjBSbF Pz9ZRy-bnKVu0ciKkdvR7L7xkt7JMeF4IFhMiBpOkgr58sKjhXgyU1adpe 4KwLU0y3nasIjrsPromU18HQV2pRbZD4eAeZbZUn5dAZ5Q\&user=ljdX fA8AAAAJ

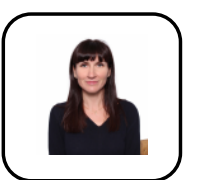

Tumanova Elena, PhD, Associate Professor,

V. I. Vernadsky Crimean Federal University, Simferopol

The topic of the protected dissertation in 2009 is "Development of investment activity in agricultural enterprises". Author of 68 publications, of which 23 scientific articles are in the editions of the Higher Attestation Commission, 35 abstracts are in the collections of international, all-Ukrainian and all-Russian conferences; co-author of one monograph, 7 textbooks.

Research interests: state regulation of financial relations, financial markets, financial monitoring

ORCID iD 0000-0001-6281-5625

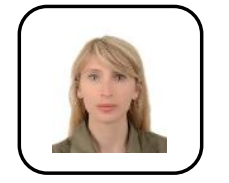

Voroshilo Viktoria, $\mathrm{PhD}$, Associate Professor,

V. I. Vernadsky Crimean Federal University, Simferopol

The theme of the protected dissertation in 2012 "Household finances in the financial system of the state". $\mathrm{He}$ is the author of 48 publications, including 2 collective monographs, 18 articles in professional editions of Ukraine, more than 20 theses of reports in the collections of scientific and practical conferences, the author of 3 textbooks.

Research interests: household Finance, household financial security, tax system, tax crimes

ORCID iD 0000-0001-8338-0659

Google Scholar ID:

https://scholar.google.com/citations?hl=ru\&pli=1\&user=k8XLOCIAAA AJ

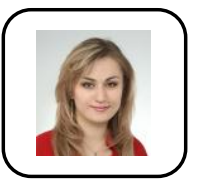

Bekirova Sevil, $\mathrm{PhD}$ in Economics, Associate Professor, Institute of Economics and Management (structural subdivision), FSAEI HE «V.I. Vernadsky Crimean Federal University», Simferopol, Russian Federation.

The theme of the protected dissertation in 2013: "Economic regulation of the development of sanitary and spa development". He is the author of 104 publications, including 3 collective monographs, 14 articles in professional journals, 23 articles and publications in popular science editions, 62 articles and abstracts in all-Ukrainian and international conferences.

Research interests: economic regulation of the development of the recreational complex; financial Relations at the micro, meso- and macro Levels, monetary methods of economic regulation; personal and social insurance; banking.

ORCID iD 0000-0002-4364-0097 